Case 2.-Female aged 23 years. Iprindole prescribed for postinfluenzal depression. $\mathrm{Hb}$ and E.S.R. normal. Eight days after first taking the drug suddenly developed pain in the right hypochondrium and right posterior chest with transient fever (temperature taken by the patient and found to be $101^{\circ} \mathrm{F}$. $\left(38.3^{\circ} \mathrm{C}\right.$.) )

When seen on the tenth day, apyrexial, marked tenderness present in the right hypochondrium, definite clinical jaundice. Urine strongly positive for bile.

Liver function tests taken the same day were as follows: Serum bilirubin $1.0 \mathrm{mg} . / 100 \mathrm{ml}$. S.G.P.T. 45 units $/ \mathrm{ml}$; cephalin cholestero flocculation positive; colloidal gold flocculation negative; alkaline phosphatase $23.5 \mathrm{~K}$.A. units zinc sulphate turbidity 8 units; total serum proteins 7.8; albumin 4.0 , globulin $3.8 \mathrm{~g} . / 100 \mathrm{ml}$.

The patient made a rapid recovery, jaundice disappearing by the twelfth day and bilirubinuria clearing by the fourteenth day. Reticulocyte-count and blood film were normal and liver function tests substantially unchanged on the twelfth day after beginning the drug.

Case 3.-Female aged 30 years. Iprindole prescribed for anxiety-depressive symptoms, as amitriptyline caused drying of the mouth. Eight days after starting the drug she developed upper abdominal pain, fever ("felt as if I had 'flu"), and flatulence.

When seen the following day apyrexial, not icteric, slight hepatic tenderness, urine negative for bile. Iprindole was discontinued.

Liver function tests the same day: Bilirubin 0.4 mg./100 ml.; S.G.P.T. 52; cephalin cholesterol flocculation positive; colloidal gold flocculation negative; alkaline phosphatase 11.5 K.A. units; zinc sulphate turbidity 6 units; total serum protein 7.4 ; albumin 4.2 , globulin 3.2 g. $/ 100 \mathrm{ml}$.

By the thirteenth day the patient felt well. There were no abnormal signs. All the liver function tests were essentially unchanged.

Case 4.-Female aged 38 years. Developed upper abdominal pain 11 days after starting iprindole for depression.

Examination at this time revealed tenderness in the right hypochondrium but no jaundice or fever. Urine negative for biliurubin. Liver function tests not done. Iprindole was discontinued and all symptoms subsided compl tely over the next four days. This was our first case, and the significance of her symptoms was appreciated only in retrospect.

We suggest that these patients exhibit similar features to those already reported. They show evidence of hepatic dysfunction about one week after starting iprindole. In view of the short time that this drug has been in general use the evidence of its hepatotoxicity which has already appeared is disturbing. As alternative tricyclic drugs are available with little or no evidence of adverse reactions, we would suggest that iprindole be withdrawn by the manufacturers.-We are, etc.

\section{F. HARRISON.}

I. M. Stanley.

Sherburn-in-Elmet,
Leeds.

\section{Pulmonary Failure after Peripheral Injury}

SIR,-I have experience of two cases of the condition described in your leading article (3 October, p. 5). The patients were previously healthy young people suffering from multiple fractures sustained in road accidents. In both cases the initial shock was fully corrected by transfusions of blood and low molecular weight dextran but they had not been overtransfused.

In one case the onset of haemorrhagic pulmonary oedema was very dramatic and the patient literally drowned in a matter of minutes in the haemorrhagic fluid which welled up from the trachea. In the other case the condition was corrected by an immediate venesection and administration of diuretics and oxygen. In neither case had gas mixtures with a high concentration of oxygen been given in the early stages.

The administration of low molecular weight dextran would seem to be a dangerous procedure once pulmonary oedema is established. Low molecular weight dextran is hyperoncotic and leads to a further increase in the circulating blood volume.

The part played by fat embolism in the aetiology of this condition may be considerable, but the syndrome differs so markedly from the usual picture of fat embolism that t would appear to be fundamentally different in some ways.-I am, etc.

\section{Guest Hospital,
Dudley.}

\section{J. A. O'GARRA.}$$
\text { Dudley. }
$$

\section{Vasculitis in Coeliac Disease}

SIR,-We were interested in Professor C. C. Booth's description of arteritis complicating coeliac disease (3 October, p. 14), as we have under observation a patient with coeliac disease with many unusual manifestations, including evidence of vasculitis in the skin.

A housewife aged 50 developed symptoms of anaemia in 1967. This was investigated elsewhere and evidence was found of folate and iron deficiency. Later she developed oedema due to hypoalbuminaemia and coeliac disease was suspected on the basis of low D-xylose excretion. She was placed on a gluten-free diet but did not adhere to this strictly.

She was referred to one of us (S.O.) in October 1968 very ill with weight loss, diarrhoea, and gross ascites and oedema. Investigations showed evidence of malabsorption (faecal fat $15 \mathrm{~g}$./day, D-xylose excretion $2.7 \mathrm{~g}$. in 5 hours), and jejunal biopsy showed subtotal villous atrophy. As in Professor Booth's patient, the enterocytes were flat and in some places absent, and there was prominent collagen beneath th: $\mathrm{m}$. Ileal involvenient was suggested by a serum $B_{12}$ level of $50 \mu \mu \mathrm{g} . / \mathrm{ml}$. There was hypoproteinaemia (serum albumin $2.1 \mathrm{~g} . / 100 \mathrm{ml}$. globulin $1.4 \mathrm{~g} . / 100 \mathrm{ml}$.) and labelling of the serum proteins with ${ }^{51} \mathrm{CrCl}_{3}$ showed this to be due to protein-losing entoropathy. After intravenous injection of $100 \mu \mathrm{Ci}{ }^{51} \mathrm{CrCl}_{2}, 25 \%$ of the dose was lost in the stools in $5^{3}$ days (normal $<1 \%$ ) and plasma half-life of the isotope was 1.5 days (normal 9.5 days ${ }^{1}$ ).

She was treated with a gluten-free diet, replacement therapy, and diuretics, but remained critically ill. In view of the protein-losing state and ileal involvement prednisolone $30 \mathrm{mg}$./day was added to her regimen, and this caused a remarkable improvement, with clearing of the oedema and ascites and a rise in serum protcin (albumin $3.7 \mathrm{~g} . / 100 \mathrm{ml}$., globulin $2.2 \mathrm{~g} . / 100 \mathrm{ml}$.) Repeat jejunal biopsy in March 1969 showed improvement, with only partial villous atrophy. Prednisolone dosage was therefore reduced to $15 \mathrm{mg}$./day with no symptomatic change, but there was a fall in serum proteins and evidence of protein-losing enteropathy persisced (5-day ${ }^{51} \mathrm{CrCl}_{3}$ loss in stools $9 \%$ of dose). In June 1969 she developed a dermatosis which rapidly became generalized; this was thought to be pemphigus erythematosus (Dr. G. Auckland). Skin biopsy showed a chronic inflammatory infiltrate closely applied to the basal layer of epidermis and also around capillaries in the dermis. Treatment with local hydrocortisone and increase in oral prednisolone to $40 \mathrm{mg}$./day produced a slow improvement in her condition, but during this time she had several grand mal convulsions. These were controlled with phenobarbitone.

The rash eventually cleared completely and her condition has remained very satisfactory apart from occasional fits. Serum proteins returned completely to normal (albumin $4.5 \mathrm{~g}$./ $100 \mathrm{ml}$., globulin $2.2 \mathrm{~g} . / 100 \mathrm{ml}$.). She remains on a strict gluten-free diet, folic acid $5 \mathrm{mg}$. t.d.s., prednisolone $30 \mathrm{mg}$ /day, and phenobarbitone $30 \mathrm{mg}$. t.d.s.

The diagnosis of coeliac disease is not fully established in this patient in that challenge with gluten has not been tried. In view of the severity of the initial illness and deterioration on reduced steroid dosage we have not felt justified in attempting this test. However, her clinical picture at the onset seems characteristic and her well-being at the present stage makes it unlikely that she has a lymphoma of the small intestine. There is undoubted evidence of vasculitis in the skin biopsy, similar to that of lupus erythematosus, but $\mathrm{L}$. E. cells were not found and antinuclear factor was absent. Numerous dermatoses have been described in association with coeliac disease ${ }^{2}$ to our knowledge, however, pemphigus erythematosus has not been previously reported.

Neurological manifestations of coeliac disease, including convulsions, are uncommon and their pathogenesis unclear. Pyridoxine deficiency has been suggested, ${ }^{3}$ but a course of this in our patient had no effect on the E.E.G. or on the frequency of the fits. It is conceivable that they could be a manifestation of vasculitis.-We are, etc.

\section{J. Holdstock.}

S. OleEsKY.

M3 Unit,
Royal Infirmary,
Manchester.

REFERENCES

Walker-Smith, J. A., Skyring, A. P., and Mistilis, S. P., Gut, 1967, 8, 166. .

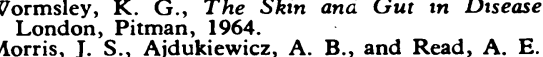

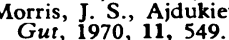

\section{Other Side of Table Mountain}

SIR,-Leaving aside Dr. Joyce E Leeson's rather unfair comment (12 September, p. 648) that "Professor Jackson would not know about that"- "that" being tuberculosis and malnutrition among the non-White population-I should like to ask her just one question. Does she think that doctors who leave South Africa "for the sake of their principles" do more good than those who stay and work among and for the non-White people to the best of their medical ability?

Perhaps some doctors who hold Dr. Leeson's views should join the splendid man she mentions in her letter (Dr. Guy Daynes in the Transkei).-I am, etc.,

\section{W. P. U. JACKSON.}

Department of Medicine, niversity of Cape Town. 